Ifølge nye tall fra norsk klinisk virkelighet skjer godt over $50 \%$ av alle innleggelser i akuttpsykiatrien med bakgrunn i selvmordsrisiko (Mellesdal et al., 2009). Men de pasientene som dette handler om, representerer en stor og heterogen gruppe med sannsynligvis sterkt forskjellige behandlingsbehov. Eksempelvis vet vi ikke sikkert om innleggelse i psykiatrisk avdeling er det beste for alle. Mange ville kanskje hatt mer nytte av andre behandlingstilbud dersom de hadde vært tilgjengelige. Skal vi kunne gi den enkelte et tilpasset og kunnskapsbasert behandlingstilbud, er det nødvendig at vi bruker differensierende tilnærminger, noe som også er understreket i de nasjonale retningslinjene for forebygging av selvmord i psykisk helsevern (Sosial- og helsedirektoratet, 2008). Vårt mål i denne sammenhengen er å redusere antallet av selvmord og selvmordsfors $\emptyset \mathrm{k}$ blant alle som er brukere av psykisk helseverntjenester. Da trenger vi å arbeide mer systematisk for å kartlegge og vurdere selvmordsrisiko og iverksette beskyttelsestiltak. Likevel er det med dagens kunnskapsstatus vanskelig å vite med noen grad av sikkerhet hvem som vil komme til å ta sitt eget liv blant de mange risikoutsatte. Derfor bør vi satse mye på å gi en så god og oppdatert behandling av den psykiske grunnlidelsen med de tilknyttede problemene som mulig. I dette nummeret av Suicidologi har vi valgt å fokusere på selvmordsforebygging overfor personer med psykoselidelser. Du vil finne artikler om studier av risikofaktorer som viser at risikobildet er et noe annet blant personer med psykoselidelser sammenliknet med befolkningen ellers, og dette er det svært viktig å være oppmerksom på. God kunnskap om slike risikofaktorer bør prege våre ulike forebyggende tiltak og behandlingsopplegg. I dette nummeret vil du derfor finne artikkelstoff der pasienter med psykoselidelser er målgruppen for tiltakene og der det er høstet positive erfaringer. God lesning!

\section{Lars Mehlum \\ Redaktør}

Referanser

Mellesdal L, Mehlum L, Wentzel-Larsen T, Kroken R, ]ørgensen HA. [In Press 2009]

Suicide risk and acute psychiatric readmissions: a prospective cohort study. Psychiatric Services

Sosial- og helsedirektoratet. (2008). Nasjonale retningslinjer for forebygging av selvmord i psykisk helsevern. (IS-1511/2008). Oslo: Sosial- og helsedirektoratet.

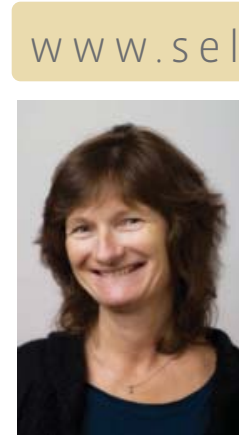

\section{Nytt} fra NSSFs Internettsider

Ved Kirsti Amundsen

6. Nasjonale konferanse om selvmordsforebygging, Trondheim Her finner du

- plenarforedrag

- abstract-bok med innlegg fra symposier, frie foredrag og postere.

Ny norsk suicidologisk forskning publisert internasjonalt

Lista oppdateres kontinuerlig.

Nytt standardverk i suicidologi

Her finner du peker til Oxford textbook of suicidology and suicide prevention - Redigert av D. \& C. Wasserman.

NSSF - Ny forkortelse for Nasjonalt senter for selvmordsforskning og -forebygging

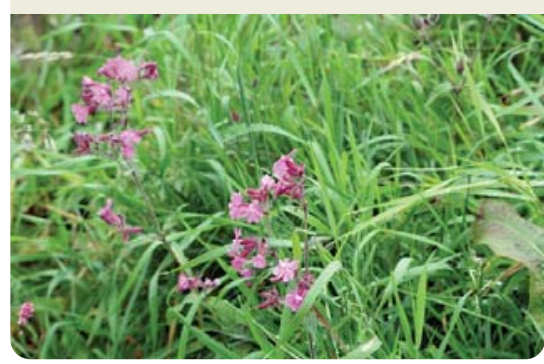

\title{
Redaksjonelle medarbeidere
}

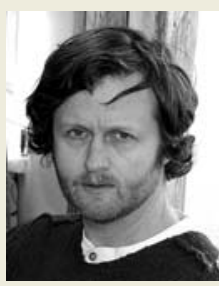

Arne Thorvik er utdannet lege, psykiater og psykoterapiveileder og har gjennomført 2 års filosofistudier. Han er til daglig overlege i Psykiatrien i Vestfold, og er i ferd med å gjøre ferdig en doktoravhandling med tittel "Suicid som etisk fenomen - teori og empiri".

Hans interessefelt er kvantitativ forskning, vitenskapsteori og vitenskapshistorie. Han har publisert artikler innen fagfelt suicidologi og rettspsykiatri.

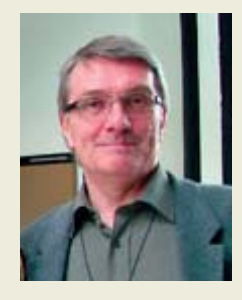
Dag Willy Tallaksen er utdannet psykiatrisk sykepleier og har hovedfag i sykepleievitenskap, samt klinisk erfaring fra psykiatri og rusmiddelomsorg. Han har i en årrekke vært ansatt ved Høgskolen i Akershus, de siste årene som førstelektor med Videreutdanning i psykisk helsearbeid som primært arbeidsområde. 2000-02 var han ansatt som undervisningskonsulent ved NSSF. Videre har han deltatt i oppbyggingen av Undervisningsprogrammet Vivat i Norge og er i dag teamleder i Vivat. 